\title{
Reduced Coenzyme I Peroxydase Activity of Murine Leprosy Bacillus
}

\author{
TATsuo MORI, KaYoKo DOMAE and KenjI KOHSAKA \\ Department of Leprology, Research Institute for Microbial Diseases, Osaka University
}

It has become clear that the reduced coenzyme I (NADH) produced by malic dehydrogenase is oxidized by Diaphorase I but the route by which NADH is oxidized in the murine leprosy bacillus is not know. Since there is no cytochrome system in the murine leprosy bacillus, catalyzation by oxygen in air will not take place. In cultivating the organism in vitro, a pathway for the hydrogen of NADH must be made inorder that energy may be produced, else cultivation is not possible. Elucidation of the conditions which will adequately fulfil the flow of electrons will become an important starting point for the in vitro cultivation of the murine leprosy bacillus.

As the initial step, it has been found that NADH is converted to NAD and water by NADH peroxydase in the presence of $\mathrm{H}_{2} \mathrm{O}_{2}$. This NADH peroxydase is present not only in murine leprosy bacillus but is also present in vitro cultivated M. Jucho and BCG. The enzyme is easily inactivated by heat but is stable to dialysis.

When the murine leprosy bacillus is present in the host cell, $\mathrm{H}_{2} \mathrm{O}_{2}$ is produced by the cell so the flow of electrons may proceed smoothly and energy produced through the action of NADH peroxydase but utilization of this pathway is difficult in vitro.

(We are partially indebted to the aid of WHO's fund. Prof. S. Nishimura) 
レプラ 33,4

\title{
鼠瀨菌の NADH-Peroxydase 活性
}

\author{
森龍男, 堂前嘉代子, 高坂健二 \\ 大阪大学微生物病研究所 瀬研究部 \\ （主任 西村真二 教授） \\ （受付 1964.10.22）
}

\section{緒言}

著者らゆはここ数年来そらい菌の呼吸䤃素系を研究し てきたが，リンコ酸脱水素醭素により生成された還元助 醉菜 I（NADH）の酸化機構が不明であった。NAD Hはデアホラーゼにより triphenyl tetrazolium chloride (TTC)を水菜受容体として酸化さ机るが, 生体内にはT TCのでときものは存在しないので，生理的状態に捄い てはいかなる機棈により酸化されるか在種々検討した。 Grant ら21 Trypanosoma rhodesience のエネルギー

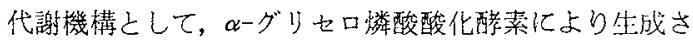
れたジハイドロオキシアセトン燐酸にNADHの水素が 伝详されて再び ことを埌告しているが，森引らはそらい菌についてての

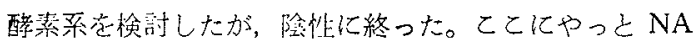
DH-peroxydase 酒より NADH酸化されることを見 活した。NADH-peroxydase については古来多くの研 究がなされている。 Tanenbaum4)が Acetobacter per. oxidans で NADPH-peroxyase を, Morton ${ }^{5}$ が Clostridium perfringens で NADH-peroxydase zawa ${ }^{6)}$ は西洋わさびで, NADH，NADPH-peroxydase を埌告している。NADH-peroxydase について最も洋細 化研究したのは Dolin 7) 8) 9) 10)で Streptoccocus faecalis の無緗胞抽江液加ら NADH-peroxydase 在精製し,

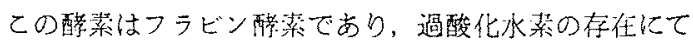
NADHを酸化してNADと水を止成するととを報告し ている。

チトクロームをむた妨らい菌の終森呼吸系の1つと して NADH-peroxydase がみつかったてとは, 前㟍11 に報告したそらい菌のフラビンの特異性とも関逨して甚 だ與味があり，そらい菌の人工培養への手がかりとして 重要な点であると想う。

\section{実験材料及び方法}

そらい菌ハワイ株はC $3 \mathrm{H}$ 今 × C F 1 早の雑種マウス の胸部皮下に生じた結節より，そらい菌熊本株はフーデ
ットラットの䍟部皮下に生じた結節より，低速遠沈法 ${ }^{12)}$ により策菌した。

獣調菌及びBCGはソートン変法培地汇夫々 4 日及び 3 週間培盖の菌を無菌的によく洗深し，M/20, $\mathrm{pH} 7.0$ の燐酸緩衝液に照濁し，6時開， $37^{\circ} \mathrm{C}$ 亿通気して後醌 酸楥衝液 $\mathrm{M} / 10, \mathrm{pH} 5.0 \mathrm{~K}$ 亿酸性亡して一夜水室に放置 せしめて，菌体保有の栄盖源の starvationを行なった。 無細胞抽汁液の調製法, 集菌したそらい菌は凍結乾燥 し，培䔄した菌は滤緍にて水分を十分除き，石英砂とと もに $0.25 \mathrm{M}$ sucrose $\mathrm{M} / 10 \mathrm{pH} 7.00$ 燐酸緩衝没でペース

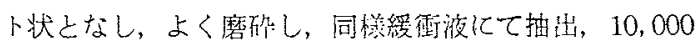
$\mathrm{rpm} 30$ 分遠沈の後, この上清を Spinco L型の超遠䟘機 にて 40,000 rpm 90分間遠沈した後，囟沈管の底に穴を あけて中酋の透明な部分を採雹した。

NADH-peroxydase 活性の測定法はベックマン型日立 光電你光光度計にて $340 \mathrm{~m} \mu$ の A D H の吸光度の減少 を追跡した。

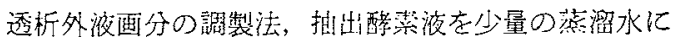
対し一夜透析し，その透析外液を Norite A 亿吸着し， よく蒸溜水で洗㵀した後，1\%アンモニヤアルカリ性50 \%アルコール及び1\%アンモニヤアルカリ性50\%アセ卜

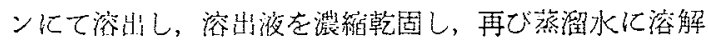
して pHを中性にした。

NA DHは Nutritional Chemical Corporation 製のも $\sigma \mathrm{H}_{2} \mathrm{O}_{2}$ は和光純薬製のものを用いた。

\section{実験 結 果}

過酸化水素によりNADHが直接酸化されないように 反応液中に牛血清アルブミン Fraction V 索加えた。

Table 1 及び Fig. 1 において対照 $\mathrm{C}_{1}$ は $\mathrm{H}_{2} \mathrm{O}_{2}$ により分 解されるNADHを見たものであるが，殆ど变化がな い。また対照 $\mathrm{C}_{2}$ は $\mathrm{H}_{2} \mathrm{O}_{2}$ なし NADH加酸化される NADH-oxydase 活性を見たものであるが，蒉だ活性が 弱い。しかしながら $\mathrm{H}_{2} \mathrm{O}_{2}$ の存在においては著明な $\mathrm{NA}$ DHの酸化がみられた。とこに用いた醉䒺液は粗製抽出 液であるため，何か不明の物戕が介在していて，NAD Hにより還元されたすのが水嘽の供与体となっているの 
Table 1 NADH-peroxydase activity of the ground extract of murine leprosy bacilli, Kumamoto strain

\begin{tabular}{|c|c|c|c|c|c|c|c|}
\hline \multicolumn{3}{|c|}{+} & \multicolumn{5}{|c|}{$\begin{array}{l}\text { Optical density of NADH at } 340 \mathrm{~m} \mu \\
0 \text { min. } 15 \mathrm{~min} . \quad 30 \mathrm{~min} . \quad 45 \mathrm{~min} . \quad 65 \mathrm{~min} .\end{array}$} \\
\hline 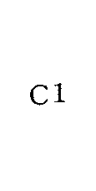 & $\begin{array}{l}\text { phosphate buffer } \\
0.25 \% \text { bovine serum } \\
\text { albumin fraction V } \\
\mathrm{NADH}\left(6 \times 10^{-7} \mathrm{~mol}\right) \\
\mathrm{H}_{2} \mathrm{O}_{2}\left(3.5 \times 10^{-6} \mathrm{~mol}\right)\end{array}$ & $\begin{array}{l}3.0 \mathrm{ml} \\
0.1 \mathrm{ml} \\
0.1 \mathrm{ml}\end{array}$ & 0.70 & 0.64 & 0.63 & 0.60 & 0.59 \\
\hline $\mathrm{C} 2$ & $\begin{array}{l}\text { *enzyme solution } \\
\text { NADH }\left(6 \times 10^{-7} \mathrm{~mol}\right) \\
\text { water }\end{array}$ & $\begin{array}{l}\text { 3. } 0 \mathrm{ml} \\
0.1 \mathrm{ml} \\
0.1 \mathrm{ml}\end{array}$ & 0.72 & 0.64 & 0.60 & 0.54 & 0.50 \\
\hline sample & $\begin{array}{l}\text { *enzyme solution } \\
\mathrm{NADH}\left(6 \times 10^{-7} \mathrm{~mol}\right) \\
\mathrm{H}_{2} \mathrm{O}_{2}\left(3.5 \times 10^{-6} \mathrm{~mol}\right)\end{array}$ & $\begin{array}{l}3.0 \mathrm{ml} \\
0.1 \mathrm{ml} \\
0.1 \mathrm{ml}\end{array}$ & 0.68 & 0.47 & 0.34 & 0.25 & 0.125 \\
\hline
\end{tabular}

*The ground extract $5 \mathrm{ml}$ of lyophylized $0.2 \mathrm{~g}$ murine leprosy bacilli, Kumamoto strain was centrifuged for $60 \mathrm{~min}$. at $35,000 \mathrm{rpm}$. The clear zone of the supernatant was used.

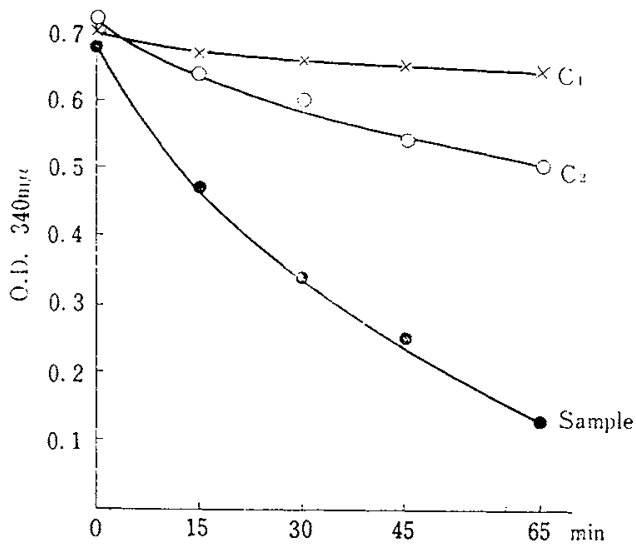

Fig. 1. Cell free extract of murine leprosy bacilli

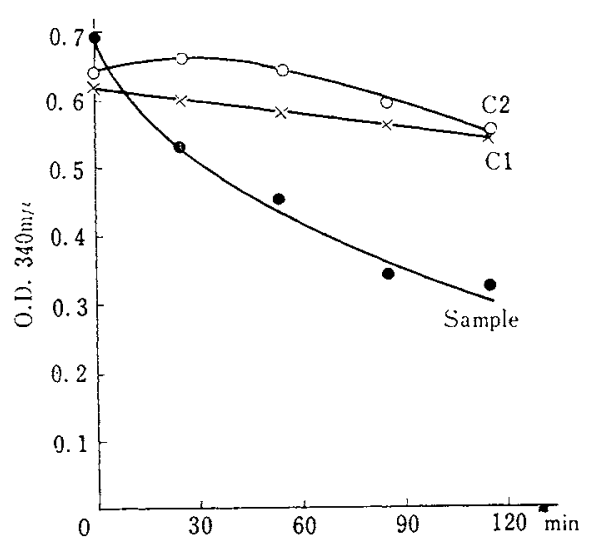

Fig. 2. Cell free extract of $B C G$

Table 2 NADH-peroxydase activity of the ground extract of BCG

\begin{tabular}{|c|c|c|c|c|c|c|c|}
\hline & & & $\begin{array}{l}\text { Optical } \\
0 \quad \text { min. }\end{array}$ & $\begin{array}{l}\text { density of } \\
25 \mathrm{~min} .\end{array}$ & $\begin{array}{l}\text { NADH a } \\
55 \text { min. }\end{array}$ & $\begin{array}{l}340 \mathrm{~m} \mu \\
85 \mathrm{~min}\end{array}$ & $115 \mathrm{~min}$. \\
\hline$C 1$ & $\begin{array}{l}\text { phosphate buffer } \\
\text { bovin s. album. f. V } \\
\mathrm{NADH}\left(6 \times 10^{-7} \mathrm{~mol}\right) \\
\mathrm{H}_{2} \mathrm{O}_{2}\left(10^{-5} \mathrm{~mol}\right)\end{array}$ & $\begin{array}{l}2.0 \mathrm{ml} \\
1.0 \mathrm{ml} \\
0.1 \mathrm{ml} \\
0.1 \mathrm{ml}\end{array}$ & 0.62 & 0.60 & 0.58 & 0.56 & 0.54 \\
\hline $\mathrm{C} 2$ & $\begin{array}{l}\text { *enzyme solution } \\
\text { bovin s. album. f.V } \\
\text { NADH }\left(6 \times 10^{-7} \mathrm{~mol}\right) \\
\text { water }\end{array}$ & $\begin{array}{l}2.0 \mathrm{ml} \\
1.0 \mathrm{ml} \\
0.1 \mathrm{ml} \\
0.1 \mathrm{ml}\end{array}$ & 0.64 & 0.66 & 0.64 & 0.59 & 0.55 \\
\hline Sample & $\begin{array}{l}\text { *enzyme solution } \\
\text { bovin s. album. f. V } \\
\mathrm{NADH}\left(6 \times 10^{-7} \mathrm{~mol}\right) \\
\mathrm{H}_{2} \mathrm{O}_{2}\left(10^{-5} \mathrm{~mol}\right)\end{array}$ & $\begin{array}{l}2.0 \mathrm{ml} \\
1.0 \mathrm{ml} \\
0.1 \mathrm{ml} \\
0.1 \mathrm{ml}\end{array}$ & 0.69 & 0.53 & 0.45 & 0.34 & 0.32 \\
\hline
\end{tabular}

*The ground extract $20 \mathrm{ml}$ of wet weights $6.3 \mathrm{~g} \mathrm{BCG}$ bacilli was centrifuged for $\overline{90}$ min. at $40,000 \mathrm{rpm}$. The clear zone of the supernatant was used. 
Table 3 NADH-peroxydase activity of the ground extract of Myco. Jucho

\begin{tabular}{|c|c|c|c|c|c|c|}
\hline & \multicolumn{4}{|c|}{ Optical density of $\mathrm{NADH}$ at $340 \mathrm{~m} \mu$} \\
\hline & & & $0 \mathrm{~min}$. & $10 \mathrm{~min}$. & $25 \mathrm{~min}$. & $40 \mathrm{~min}$. \\
\hline $\mathrm{C} 1$ & $\begin{array}{l}\text { *enzyme solution } \\
\text { bovin s. album. f. V } \\
\text { phosphate buffer } \\
\text { NADH }\left(6 \times 10^{-7} \mathrm{~mol}\right) \\
\text { water }\end{array}$ & $\begin{array}{l}1.0 \mathrm{ml} \\
1.0 \mathrm{ml} \\
1.0 \mathrm{ml} \\
0.1 \mathrm{ml} \\
0.1 \mathrm{ml}\end{array}$ & 0.55 & 0.52 & 0.48 & 0.42 \\
\hline $\mathrm{C} 2$ & $\begin{array}{l}\text { *enzyme solution } \\
\text { bovin s. album. f. V } \\
\text { phosphate buffer } \\
\text { NAD }\left(6 \times 10^{-7} \mathrm{~mol}\right) \\
\text { water }\end{array}$ & $\begin{array}{l}\text { 1. } 0 \mathrm{ml} \\
1.0 \mathrm{ml} \\
1.0 \mathrm{ml} \\
0.1 \mathrm{ml} \\
0.1 \mathrm{ml}\end{array}$ & 0.10 & 0.27 & 0.31 & 0.29 \\
\hline Sample & $\begin{array}{l}\text { *enzyme solution } \\
\text { bovin s. album } f . V \\
\text { phosphate buffer } \\
\mathrm{NADH}\left(6 \times 10^{-7} \mathrm{~mol}\right) \\
\mathrm{H}_{2} \mathrm{O}_{2}\left(10^{-5} \mathrm{~mol}\right)\end{array}$ & $\begin{array}{l}\text { 1. } 0 \mathrm{ml} \\
1.0 \mathrm{ml} \\
1.0 \mathrm{ml} \\
0.1 \mathrm{ml} \\
0.1 \mathrm{ml}\end{array}$ & 0.51 & 0.38 & 0.29 & 0.24 \\
\hline
\end{tabular}

*The ground extract $25 \mathrm{ml}$ of wet weights $4.8 \mathrm{~g}$ Myco. Jucho was centrifuaed for $90 \mathrm{~min}$ at $40,000 \mathrm{rpm}$. The clearzone of the supernatant was used.

Table 4 The effect of dialytic iraction to the NADH-peroxydase activity of dialyzed enzyme (BCG)

\begin{tabular}{|c|c|c|c|c|c|c|c|}
\hline & & & $\begin{array}{l}\text { Optical } \\
0 \text { min. }\end{array}$ & $\begin{array}{l}\text { Aensity of } \\
10 \mathrm{~min} \text {. }\end{array}$ & $\begin{array}{l}\text { NADH } \\
20 \mathrm{~min} .\end{array}$ & $\begin{array}{l}340 \mathrm{~m} \mu \\
35 \mathrm{~min} .\end{array}$ & $50 \mathrm{~min}$. \\
\hline $\mathrm{C} 1$ & $\begin{array}{l}\text { *fractionated enzyme } \\
\text { phosphate buffer } \\
\text { bovin serum albumine } \\
\text { NADH }\left(6 \times 10^{-7} \mathrm{~mol}\right) \\
\text { water }\end{array}$ & $\begin{array}{l}2.0 \mathrm{ml} \\
0.5 \% \\
1.1 \mathrm{ml} \\
0.1 \mathrm{ml} \\
0.2 \mathrm{ml}\end{array}$ & 0.54 & 0.49 & 0.44 & 0.39 & 0.33 \\
\hline $\mathrm{C} 2$ & $\begin{array}{l}\text { *fractionated enzyme } \\
\text { phosphate buffer } \\
\text { bovin serum albumine } \\
\mathrm{NADH}\left(6 \times 10^{-7} \mathrm{~mol}\right) \\
\mathrm{H}_{2} \mathrm{O}_{2}\left(3.5 \times 10^{-6} \mathrm{~mol}\right) \\
\text { water }\end{array}$ & $\begin{array}{l}2.0 \mathrm{ml} \\
0.5 \% \\
1.0 \mathrm{ml} \\
0.1 \mathrm{ml} \\
0.1 \mathrm{ml} \\
0.1 \mathrm{ml}\end{array}$ & 0.51 & 0.365 & 0.28 & 0.20 & 0.12 \\
\hline Sample & $\begin{array}{l}\text { *fractionated enzyme } \\
\text { phosphate buffer } \\
\text { bovin serum albumine } \\
\mathrm{NADH}\left(6 \times 10^{-7} \mathrm{~mol}\right) \\
\mathrm{H}_{2} \mathrm{O}_{2}\left(3.5 \times 10^{-6} \mathrm{~mol}\right) \\
\text { dialytic fraction }\end{array}$ & $\begin{array}{l}2.0 \mathrm{ml} \\
0.5 \% \\
1.0 \mathrm{ml} \\
0.1 \mathrm{ml} \\
0.1 \mathrm{ml} \\
0.1 \mathrm{ml}\end{array}$ & 0.53 & 0.365 & 0.27 & 0.20 & 0.12 \\
\hline
\end{tabular}

*The ground extract $100 \mathrm{ml}$ of wet weightd $23.8 \mathrm{~g}$ BCG bacilli was centrifuged for $40 \mathrm{~min}$. at $10,000 \mathrm{rpm}$. The supernatant was dialyzed overnight against a small volume of distilled water, and was fractionated with ammoniumsulfate. The enzyme fraction between $1 / 3$ and $2 / 3$ ammoniumsulfate saturation was dialyzed and was centrifuged for $60 \mathrm{~min}$. at $40,000 \mathrm{rpm}$. The supernatant was used. 


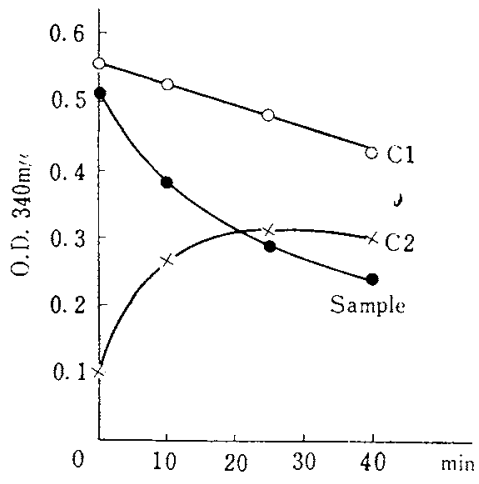

Fig. 3. Cell free extract of Myco. jucho

かも知机ない。とのような中閶体を追跡するために，を らい菌を用うることは，菌の収量の面から考えて甚だ困 難であるので，培兹可能な抗酸菌として獣調菌及び B C Gを用いた。Table 2 及び Fig 2 は培羟したBCGの無 細胞抽出液による NADH-peroxydase 活性をみたもの であるか，BCGにすとの活性か标任しているととを認 めた。 BCGに NADH-peroxydase 活性があるのなら ば，非病原性抗酸菌である獣調菌にもこの活性があるだ ろうと考えて検討したとてろ Table 3，Fig 3にみられ

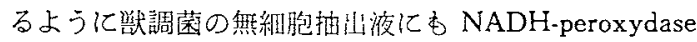
活性をみとめた。BCG及び獣調菌は通気による starv ationを行なってはいるが，それらの菌の無細胞抽出液 には菌体中の微量の基壁及びNADにつながる種々の脱 水菜酼菜が存在している。NADH-peroxydase によりN ADHがNAD酸化される一方，何らかの脱水索醇素 によりNADHの再生喭が行なわれているため，見か子 上 $\mathrm{NADH}$-peroxydase 活性は弱く表現されている。

NADHの水䒺伝達の中間体の存在老 B C G 加ら抽山 した無細胞抽出液により検討した。無細胞抽出液を蒸溜 水汇対して透析外液画分を作り，透析内液加硫安全飽

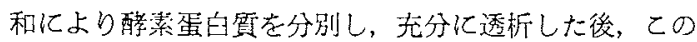
醉素液により NADH-peroxydase 活性をしらべだ。

Table 4，Fig4亿みられるように，硫安分画，透析に上 っても，NADH-peroxydase 活性は保持されているし， 又透析外液画分を加えても，活性に影響がないととろか ら，NADHにより還元される末知物颁は一応存在しな いむの上考えられる。

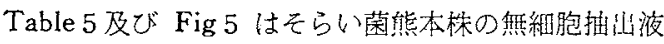
の透析及び加熱による NADH-peroxydase 活性の影響を みたものであるが，嫌気的条件にては $\mathrm{C}_{2}$ 対照にみられ るように NADH-peroxydase 酒性以外汇る NADHの

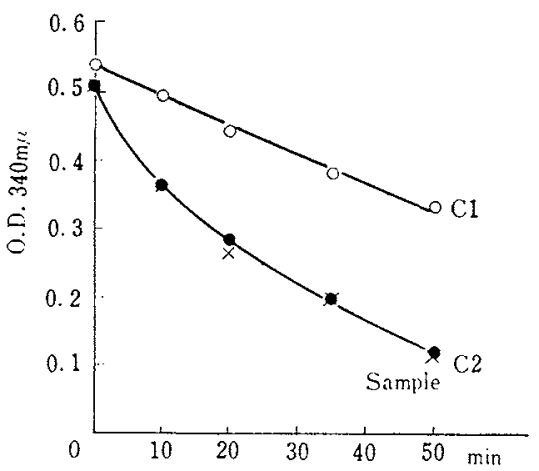

Fig. 4. Effect of dialytic fraction on the cell free extract of $B C G$

崩壊は殆どみられない。また $95^{\circ} \mathrm{C} 10$ 分間の加熱により NADH-peroxydase は完全仿失活する。乙の NADHperoxydaseは透析化対し发定であり，BCGの醇熬と同 椂，中阙体を必要としない。

\section{討論}

Dolin 7) 8) 91 10) は streptococcus faecalis から NADH. peroxydaseを精製し、この酼䒺はフラビン䣼索であり， $2 \mathrm{NADH}+\mathrm{H}_{2} \mathrm{O}_{2}=2 \mathrm{NAD}+2 \mathrm{H}_{2} \mathrm{O}$ なる反応式に 従って NADHが $\mathrm{H}_{2} \mathrm{O}_{2}$ に上り酸化さ机て $\mathrm{H}_{2} \mathrm{O}$ と NADが生ずるととを報告している。しかしながら人工 培善が不可能なそらい菌を大量に第菌して NADH-peroxydase を精製するととは甚だ困難である。もらい菌の 無細胞抽出液中には catalase 活性もあるし，又NADに つながる脱水素酵素も存在しているから， $\mathrm{H}_{2} \mathrm{O}_{2}$ の滅少 及びNADの生成を stoichiometric 亿定量することはで きなかった。今回は $\mathrm{H}_{2} \mathrm{O}_{2}$ の存在下においてNADHの 滅少を測定したにすぎなかったが，そらい菌の終末呼吸 系としてNADH-peroxydase が重要な役彗应演じている ととは筆実であるう。前報11においてそらい菌のリボ フラビンは蛋白質と結合して安定な還元型を保ち, 空気 中の酸菜によっては自動酸化性でないのだろうとのべて おいたが，そらい菌の電子伝達系代いて次のようなて とが考えられる。即ち， cytochrome 系をすたないそら い菌を空気中にとりだしても菌体内にあるフラビン醇素 の大部分岕還元型のままでとどまっているが，過酸化水 素が存在していると，との還元型フラビン醇素が再び酸 化型となり，菌体内の酸化還元による電子の流机がうま く衙いて，エネルギー獲得機構へとつながっているので あろう。これらそらい菌の in vitro 培養值結したフラ ビン酥素の問题は cytochrome 係をもたないとの菌のエ 
Table 5 The effect of heating and anaerobic condition against the NADH-peroxydase activity of the ground extract of murine leprosy bacilli, Kumamoto strain

\begin{tabular}{|c|c|c|c|c|c|c|}
\hline & & & \multicolumn{4}{|c|}{ Optical density of NADH at $340 \mathrm{~m} \mu$} \\
\hline $\mathrm{C}_{1}$ & $\begin{array}{l}\text { heated enzyme } \\
\mathrm{H}_{2} \mathrm{O}_{2}\left(3.5 \times 10^{-6} \mathrm{~mol}\right) \\
\mathrm{NADH}\left(5 \times 10^{-7} \mathrm{~mol}\right)\end{array}$ & $\begin{array}{l}3.0 \mathrm{ml} \\
0.1 \mathrm{ml} \\
0.1 \mathrm{ml}\end{array}$ & 0.56 & 0.56 & 0.55 & 0.54 \\
\hline $\mathrm{C}_{2}$ & $\begin{array}{l}\text { *enzyme } \\
\text { water } \\
\mathrm{NADH}\left(5 \times 10^{-7} \mathrm{~mol}\right)\end{array}$ & $\begin{array}{l}\text { 3. } 0 \mathrm{ml} \\
0.1 \mathrm{ml} \\
0.1 \mathrm{ml}\end{array}$ & 0.56 & 0.56 & 0.55 & 0.54 \\
\hline sample & $\begin{array}{l}\text { *enzyme } \\
\mathrm{H}_{2} \mathrm{O}_{2}\left(3.5 \times 10^{-6} \mathrm{~mol}\right) \\
\mathrm{NADH}\left(5 \times 10^{-7} \mathrm{~mol}\right)\end{array}$ & $\begin{array}{l}3.0 \mathrm{ml} \\
0.1 \mathrm{ml} \\
0.1 \mathrm{ml}\end{array}$ & 0.56 & 0.47 & 0.38 & 0.17 \\
\hline
\end{tabular}

The ground extract $15 \mathrm{ml}$ of lyophylized $0.75 \mathrm{~g}$ murine leprosy bacilli, Kumamoto strain was centrifuged for $60 \mathrm{~min}$ at $35,000 \mathrm{rpm}$. The clear zone of supernatant was dialysed against $\mathrm{M} / 10 \mathrm{pH} 7.0$ phosphate buffer and used. Heat-inactivation was carried out at $95^{\circ} \mathrm{C}$ for $10 \mathrm{~min}$.

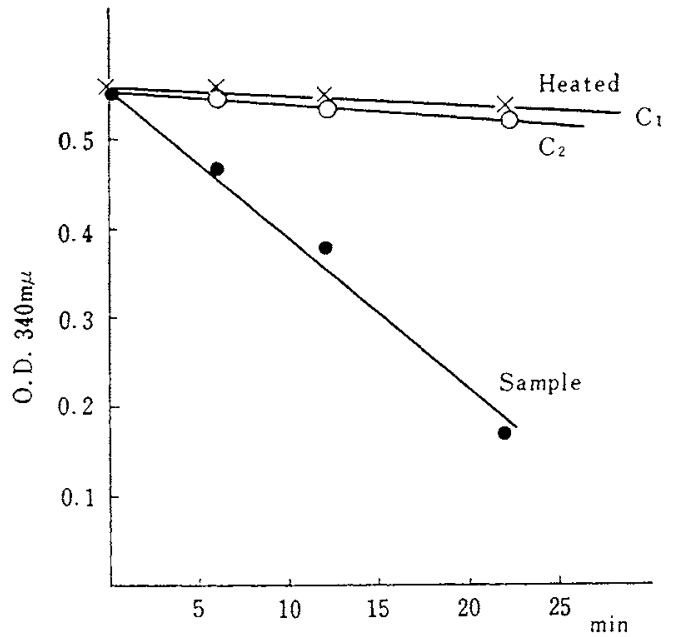

Fig. 5. Cell free extract of murine leprosy bacilli in anaerobic condition

ネルギー獾得機楧とともになお詳細な検埠を要するもの 之思う。

\section{総括}

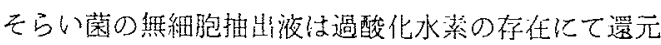
助酵菜 I を酸化する NADH-peroxydase 活性を有する。 この酵菜活性は in vivo增㽝菌のみの特性ではなく，in

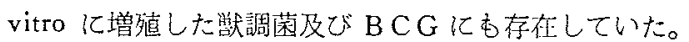
このNADH-peroxydase 敒透析に対し安定であるが，熱 に対しては不安定で失活しやすい。

\section{文献}

1) Mori, T., K. Kosaka and T. Ito : Carbohydrate Metabolism of the Murine Leprosy Bacillus, I. Studies on the Respiratory Enzyme System, especially the Diaphorase and Malic Dehydrogenase Activities. Biken's Journal 4, 225-233(1961)

2) Grant, P. T. and J.R. Sargent : Properties of L- $\alpha$-Glycero-phosphate Oxidase and its Role in the Respiration of Trypanosoma rhodesiense. Bioch. J. 76, 229-237 (1960)

3) Mori, T. : The Respiration Enzymes of Murine Leprosy Bacillus, especially Diaphorase I, II and Malic Dehydrogenase. La lepro 32, 52, 77(1963)

4) Tanenbaum, S. W. : The Metabolism of Acetobacter Peroxidans, I. Oxidative Enzymes. Biochim. et Biophys. Acta 21, 335-342 (1957)

5) Mallin, M. L. and H. W. Saley : Some Relations of Hydrogen Peroxide to Oxygen Consumption by Clostridium Perfringens. Arch. Biochem. and Biophys. 73, 306-314 (1958)

6) Akazawa, T. and E. E. Conn : The Oxidation of Reduced Pyridine nucleotides by Peroxydase. J. Biol. Chem. 232, 403-415 (1958)

7) Dolin, M.I. : The Oxidation and Peroxidation of $\mathrm{DPNH}_{2}$ in Extracts of Streptococcus faecalis. Arch. Biochem. and Biophys. 46, 483-485(1953)

8) Dolin, M.I. : The DPNH-oxidizing Enzymes of Streptococcus faecalis. It The Enzymes Utilizing Oxygen, Cytochrome C, Peroxide and 2,6-Dichlorophenol indophenol or Ferricyanide as Oxi- 
dants. Arch. Biochem. Biophys. 55, 415-435 (1955)

9) Dolin, M. I. : The Streptococcus faecalis oxidases for Reduced Diphosphopyridine nucleotide. IIl Isolation and Properties of a Flavin Peroxidase for Reduced Diphospho pyridine nucleotide. J. Biol. Chem. 225, 557-573 (1957)

10) Dolin, M. I. : The Streptococcus faecalis Oxidases for Reduced Diphosphopyridine nucleotide.
III. Properties of the Enzyme-substrate Complex formed between Reduced Diphosphopyridine nucleotide Peroxydase and Pyridine nucleotide. J. Biol. Chem. 235, 544-549 (1960)

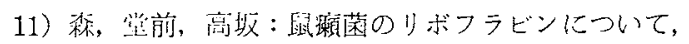
レプラ 291-295 33, (1964)

12）秝, 高坂, 伊藤, 西村: 鼠濑菌の等菌法, 口本細菌 学䧴婄, 16, 808-813 (1961) 